\title{
DOES CORRUPTION AFFECTS BUSINESS INNOVATION? INSIGHTS FROM EMERGING COUNTRIES
}

\author{
Marilen Gabriel PIRTEA (D)1, Gabriela Lucia SIPOS (D) 2*, \\ Alin IONESCU (D)2 \\ ${ }^{1}$ Department of Finance, Faculty of Economics and Business Administration, \\ West University of Timisoara, Timisoara, Romania \\ ${ }^{2}$ Department of Management, Faculty of Economics and Business Administration, \\ West University of Timisoara, Timisoara, Romania
}

Received 16 November 2018; accepted 02 April 2019

\begin{abstract}
There are very different outcomes in the literature regarding the influences of corruption on business innovation and also arguments for both "sanding the wheels" and "greasing the wheels" approaches. The main goal pursued in this paper is to broaden the understanding of the corruption influence on business innovation, considering seven representative dimensions of corruption at governmental structures and institutions' level and also four relevant dimensions of business innovation, less approached so far. The originality and relevance of this paper are based on that these seven different dimensions of corruption are targeting three characteristic features of it, as bribery's prevalence, the bribery's spread and the companies' propensity to offer gifts for overcoming the bureaucratic pressures. Moreover, the four different new dimensions of business innovation are targeting the company's propensity for innovating and strengthening its image and the way of connecting with business partners in a changing business environment. Considering an extensive data set for 110 emergent countries from four continents for the period between 2002 and 2014 and using the generalized linear model framework, this research study is emphasizing that corruption at governmental structures and institutional level has a significant negative impact on business innovation, adversely affecting innovation perspectives.
\end{abstract}

Keywords: corruption dimensions, innovation dimensions, corruption index, business innovation index, "sanding the wheels", emerging countries.

JEL Classification: D73, O31.

\section{Introduction}

Innovation is considered to be an important factor in increasing the companies' competitiveness and economic development (Janoskova \& Kral, 2015). Business innovation is perceived increasingly more as a key factor for enhancing the business viability, especially in unstable environment (Abdi et al., 2018).

*Corresponding author. E-mail: gabriela.sipos@e-uvt.ro

This is an Open Access article distributed under the terms of the Creative Commons Attribution License (http://creativecommons. org/licenses/by/4.0/), which permits unrestricted use, distribution, and reproduction in any medium, provided the original author and source are credited. 
In the last decades, corruption became a topic of great interest both due to its spread and also to its significant impact. Based on the economic theory, corruption is perceived either as a "principal agent problem" or as a "collective action problem" (Begovic, 2005; Marquette \& Peiffer, 2015). These two different approaches are considered by some authors to be mutually exclusive, while others consider them to be complementary (Stephenson, 2015). These differences of approaches may be the basis of an incomplete understanding of the phenomenon of corruption and the failure in reducing its impact on the economy.

Corruption is perceived as a negative phenomenon which occurs with varying degrees of intensity in almost all countries of the world (Tomaszewski, 2018). Although corruption appears in almost all countries, a recent study on the causes of corruption in 64 Eastern European and Middle East and North Africa transition economies is suggesting that corruption is particularly prevalent in economically less developed countries (Uberti, 2018). Besides, a highly topical report reveals that the phenomenon of corruption still remains more prevalent in emerging countries than in other ones, even though over the last few years most of the emerging countries have undergone a major changes period and have made efforts to reduce corruption (Ernst \& Young, 2018).

The relationship between corruption and innovation raises a lot of concern in the literature. The influence of corruption on innovation is not yet fully understood, especially in countries with economies in transition (Xie, Qi, \& Zhu, 2018). There is a strong relationship between corruption level and the intensity of innovation activity across countries. In some cases, corruption may have a positive influence on innovation, but not in countries facing high-level governmental corruption (Wen, Zheng, Feng, Chen, \& Chang, 2018).

Business innovation activity has proved to be highly influenced by the country's institutional environment. Thus, in a survey of companies from 20 emerging countries taking into account a database for the period 2006-2013 it is shown that especially in emerging countries corruption, as an institutional determinant, has had the most negative influence on innovation (Alam, Uddin, \& Yazdifar, 2019).

The impact of corruption on innovation differs according to a variety of factors such as: the efficiency degree of governmental structures and institutions, the extent of corruption, the innovation type, the approach level: business or national. Also, the influence of corruption on innovation varies depending on the conditions that encourage companies to pay bribes in countries with a different level of development (Chandan \& Arup, 2015). There is a vast literature mainly focused on the impact of corruption on innovation at countries level and on economic development (Mrad \& Bouaziz, 2018) and there are still few researches that analyse the impact of corruption on innovation at corporate level (Karaman Kabadurmuş, 2017).

Concerning the relationship between corruption and innovation, two different points of view emerged. A first point of view highlights the negative impact of corruption on innovation (Veracierto, 2008; Mungiu-Pippidi, 2015; DiRienzo \& Das, 2015; Paunov, 2016; Lesakova, Gundova, Kral, \& Ondrusova, 2017; Dincer, 2019; Alam, Uddin, \& Yazdifar, 2019 and others). This approach is more morally and legally correct and is known as "sanding the wheels" theory. The second point of view addresses the relationship between corruption and innovation from a perspective that is incompatible with the principles of morality and 
legality, showing that under certain conditions corruption can have a positive effect on innovation (Chandan \& Arup, 2015; Karaman Kabadurmuş, 2017; Barasa, 2018 and others). This approach is known as "greasing the wheels" theory. So, the literature provides empirical evidences for supporting both "sanding the wheels" and "greasing the wheels" approaches.

The relationship between corruption and business innovation seems to be a very complex one, as long as literature offers very different outcomes regarding the influences of corruption on business innovation under different circumstances. In many cases, the researchers' views on the impact of corruption on innovation are completely opposite. Thus, corruption causes dysfunctions in the companies' activities, also hampering their innovation activity (Krammer, 2013). Corruption can reduce the pace of innovation in companies and further on, in industries and, therefore it is approached as a key factor in determining a country's level of development (Veracierto, 2008).

But, under certain conditions, corruption is perceived as a way of overcoming bureaucratic barriers and the legal framework rigidity, facilitating the innovation process in companies (Goedhuys, Mohnen, \& Taha, 2016). The companies' propensity for innovating reflects the quality of the business environment. A stable business environment will stimulate innovation.

In the last period, due to the growing awareness of the innovation role in supporting companies' viability, there has been an increase in research concerns about the impact of corruption on business innovation, regardless of the countries level of development but especially in emergent countries and targeting different time periods. Although this increased effervescence of researches concerning about the effect of corruption on business innovation in countries from different geographic areas of the world, almost all of the recent studies are based on past periods databases, ending with 2014-2015.

Thus, in their research regarding the main factors that stifles innovation activities of small and medium-sized companies in Slovakia considering data from the period 2010-2015, Lesakova, Gundova, Kral, and Ondrusova (2017) highlighted corruption and bureaucracy as the main factors hampering business innovation. Using two different dimensions for innovation activity and two dimensions for corruption, Dincer (2019) focused his study on the longterm effect of corruption on innovation activity, considering data for the period between 1977-2006 for 48 U.S. states. His research shows that the long-time corruption has a slowing effect on innovation activity. In an extended study regarding the period between 2005-2013 on the impact of corruption on business innovation, Sena, Duygun, Lubrano, Marra, and Shaban (2018) have highlighted that the negative effect of corruption on companies' innovation activity may be dimmed by an independent management team of these companies.

On the other hand, using a company-level database for 27 countries from Eastern Europe and Central Asia, Karaman Kabadurmuş (2017) highlighted the positive impact of corruption on innovation, regardless of the dimensions considered. The results of her study support the "greasing the wheels" approach.

A very recent comprehensive study on the relationship between corruption and business innovation taking into account companies from four different activity areas from 30 countries from Central and Eastern Europe and Asia, addresses corruption as an illegal and immoral expression of entrepreneurship (Tomaszewski, 2018). In this research, the author considers two different dimensions of business innovation (hard and soft innovations) and 
argues that each of the "sanding the wheels" and "greasing the wheels" approaches aim at different perspectives of the relationship between corruption and business innovation and complement each other.

The relationship between corruption and innovation has been approached also from another perspective in the most recent researches. Anti-corruption efforts may have an impact on enhancing business innovation, highlighting the fact that the lower the institutional corruption is, the more companies are involved in the innovation activity. A recent study on anti-corruption effort in companies from China highlights that the intensity of business innovation activities raises in the context of a free of corruption institutional environment (Yu, Guo, Lettic, \& Barnes, 2019). Analysing the effects of the anti-corruption struggle started in China in 2013 on a representative sample of listed companies for the period between 2009-2015, Gang and Go (2017) have shown that anti-corruption efforts are positively correlated with the companies' propensity to innovate. Gan and Xu (2018) analysed the effects of China's anti-corruption efforts on the innovation activity of listed companies, taking into account the period between 2006-2012. Their research highlighted a more intense innovation activity of companies in areas with greater anti-corruption efforts. The results highlighted by these last studies are all the more significant as China is the world largest emerging country.

Understanding the possible effects of corruption on business innovation is more stringent in the case of emerging countries, due to the role that business innovation plays in emerging economies. On the basis of the above, can be noticed that most recent and relevant research efforts to uncover the relationship between corruption and business innovation have been made with reference to emerging economies (Alam, Uddin, \& Yazdifar, 2019; Yu, Guo, Lettic, \& Barnes, 2019; Xie, Qi, \& Zhu, 2018; Wen, Zheng, Feng, Chen, \& Chang, 2018; Gan \& Xu, 2018; Tomaszewski, 2018; Uberti, 2018; Tian, Ruan, \& Xiang, 2017; Gang \& Go, 2017). Also, based on a database for 22 emerging countries for the period 1996-2014, Kayalvizhi and Thenmozhi (2018) have proven the role of innovation as an important factor to attract foreign direct investment in emerging countries.

In this context created by spreading the corruption especially in emerging countries and the lack of fully understanding the influence of corruption on innovation, this paper aims to contribute to a deeper understanding of how corruption affects business innovation in emerging countries. This research is in line with the latest trends of increasing concerns about the effects of different forms of corruption may have on business innovation with focus on emerging countries, proving its importance and actuality.

In the endeavour of revealing the influence of corruption on business innovation in emerging countries, this paper is using a sample of 110 emerging states from different geographical areas such as Asia, Africa, Europe and Latin America for a period of 13 years (World Bank, 2018b). The dataset is available online on the World Bank databases (World Bank, 2018a). In order to check our research hypothesis regarding the possible relationships between the corruption dimensions and business innovation we firstly selected the most representative dimensions of these two concepts, basing on information and data available in the literature. For a more comprehensive approach of the corruption's influence on business innovation, this research study considers seven different dimensions of corruption targeting three characteristic features of it, as bribery's prevalence, bribery's spread and companies' 
propensity to offer gifts for overcoming the bureaucratic pressures. Also, this study is considering four different new dimensions of business innovation which approach innovation from a new perspective, less studied until now. These new dimensions of business innovation are targeting the company's propensity for innovating and strengthening its image and the way of connecting with business partners in a changing business environment.

Thus, applying the methodology of principal component analysis, we built two composite indicators in order to describe in a robust manner the main elements referring at the phenomenon of corruption and those referring at business innovation on the sample of 110 emerging countries. Secondly, in order to estimate the possible influence of the corruption index on the business innovation index we considered appropriate the methodology of generalized linear model, developed by Nelder and Wedderburn (1972), which represents a flexible technique for the generalization of ordinary least square method.

The research hypothesis of the paper was confirmed, proving that corruption affects both negatively and significantly the innovation processes of the companies in emerging countries. So, this paper brings valuable arguments in the support of the "sanding the wheels" approach.

The vast majority of the countries included in the sample of 110 emerging countries have maintained their position over the 13 years considered period and most of them are included also in present in the same income and development category. Besides, the considered 13-years period is long enough to assure the premises of just minor changes of the average values of the considered variables for the period just after the analysed time span. This reinforces the significance of the study results and gives topicality to the present empirical study.

This paper is a step forward in understanding the relationship between corruption and innovation in the specific context of emerging countries. The essential addition of this paper at the existing literature relies in considering many more dimensions for describing both corruption and business innovation. By considering four original dimensions of innovation for companies in emerging countries, this paper contributes to the discovery of new innovation facets and, in this context, reveals new perspectives to address the influence of corruption on innovation in emerging countries. The relevance of this research findings is supported by the size and diversity of the emerging countries sample covered by the research, as well as the length of the considered period of time.

Further, this paper is structured as follows. Section 1 presents a literature review on the impact of corruption on business innovation. Section 2 provides the methodology applied in this research study. The empirical results are illustrated in section 3. Conclusions are presented in the last section of the paper.

\section{Literature review}

Literature that brings arguments in support of a negative impact of corruption on innovation is very consistent and supports the "sanding the wheels" approach. DiRienzo and Das (2015) have revealed in their cross-country study that corruption is negatively affecting business innovation, showing that there is an intensified negative impact of corruption on innovation activities in less developed countries. Consistent with the results of these studies, Mahagaonkar (2010) also points out that corruption negatively influences innovation activity 
in companies, with the effect being more emphasized in countries with a low level of development. In these countries, companies need to find mechanisms and tools to overcome social and economic difficulties, as well as red tape hindrances.

These conclusions are reinforced by Ayyagari, Demirgüç-Kunt, and Maksimovic (2014) in their study covering 57 developing countries that highlights the fact that the influence of corruption upon innovation activity is more acutely felt in countries with low levels of development characterized by inefficient government structures and institutions.

So, the corruption is a very complex reality that is particularly proliferating in less developed countries with high level of bureaucracy and confined financial resources and very often it has also a political involvement (World Bank, 1997; Teodorescu, Andrei, Roșca, Profiroiu, \& Turtureanu, 2007; Radu, 2017).

Pointing out the need for developing research studies also on the microeconomic level, not just at the macroeconomic level how were mainly conducted so far, de Waldemar (2012) proves the powerful negative impact of corruption on innovation in the case of companies from India.

Also, Mungiu-Pippidi (2015) revealed that the intensity of corruption in a country influences the innovative behaviour of the companies. She argued that the stronger the control of corruption is, the greater the business innovation capacity. Therefore, high quality governance enhances the corporate innovation potential. Studying the impact of corruption on innovation in the United States, Ellis, Jared, and White (2016) suggested that corruption is hampering business innovation. Moreover, Botrić and Božić (2015) showed empirical evidences from eleven East-European countries proving that corruption has a constraint effect on the business innovation. Focusing on developing and emerging countries, Paunov (2016) analysed the influence of corruption on business innovation. In her study, she proved that corruption is a significant factor in reducing the companies' chances to obtain recognized quality certification, as a relevant business innovation dimension.

In a research study targeting companies from an emerging country, Tian, Ruan, and Xiang (2017) have proved that although there is a trend of companies to pay bribes in order to facilitate borrowing from financial institutions, the company's propensity for innovating leads to a higher degree of overcoming bureaucratic pressures in obtaining financial resources than by paying bribe. Also, Dickel and Graeff (2018) explain the entrepreneurs' propensity for corruption based on cost-benefit considerations.

The impact of corruption on innovation has been highlighted in the research studies developed so far also from the perspective of the effect of anti-corruption efforts on innovation. In their extensive research study analysing 57 countries from Europe and Central Asia covering a period of 16 years, Lau, Yang, Zhang, and Leung (2015) have found that business innovation is impelled by sustained anti-corruption efforts. Also, Dang (2016) has highlighted the positive impact of anti-corruption efforts on rising the business innovation level in China. Moreover, Anokhin and Schulze (2009) proved in their study that the business innovation level may be increased based on a reduced level of corruption.

By the other hand, there are studies regarding the impact of corruption on business innovation brining arguments in support of a positive influence. Corruption has an incentive effect on business innovation when it targets government officials in order to overcome the 
bureaucratic barriers. The positive effect of bribe paying by Chinese companies in order to overcome bureaucratic barriers was revealed in their research by Xu, Zhang, and Yano (2017). Also, Goel and Nelson (2018) suggested the positive effect of corruption on innovation based on their extensive research regarding developing countries.

This is evidenced by Chandan and Arup (2015) in their research study on Indian companies, emphasizing that paying bribe to governmental structures and institutions' officials has a positive influence on innovation in companies. The positive influence of corruption on business innovation was also noticed by Krammer (2013) in his extended study taking into consideration thirty transition economies. In this study, the corruption is seen as an assumed alternative way of entering new markets with new and innovative products.

Moreover, the literature proves that corruption is acting irregularly, its impact being different depending on the approached perspective. Blackburn and Forgues-Puccio (2009) have shown that corruption may act with different levels of intensity depending on the level of corruption networks' organization in different countries. They have studied in detail the way of corruption is acting and have shown that in countries where there is an organized environment for corruption, the negative impact of corruption on innovation is more faded than in countries where there is no organized framework for corruption.

Some researchers have revealed that in countries with less efficient governmental structures and institutions the corruption may have a positive effect on business innovation propensity, while in countries with efficient governmental structures and institutions corruption has a stronger negative impact on business innovation (Méon \& Weill, 2010; A. Ngoc, Quang, M. Ngoc, Binh, \& Tran-Nam, 2016). Goedhuys, Mohnen, and Taha (2016) have revealed in their business level study developed in companies from Egypt and Tunisia a dual influence of corruption on innovation. So, the corruption has a negative impact on the expectation that a company will be innovative and at the same time, it has a positive impact in overcoming the inefficient structures and institutions.

Ngoc et al. (2016) have studied the impact of corruption depending on its size, making a clear distinction between "the petty corruption" and "the grand corruption". In their view, "the petty corruption" may have a positive effect on business innovation, allowing getting immediate benefits for the company, especially when it comes to overcoming the inefficient structures that hinder the company's activity. In the same time, "the grand corruption" has a negative effect on business innovation and on company's long-term viability. So, their research results suggest that in the short term, corruption may have a positive impact on the business, but in the long run its impact on the business is clearly negative, significantly affecting the business development.

In their research regarding the impact of corruption on innovation in an international framework and focusing on transition countries, Habiyaremye and Raymond (2018) have brought new evidence on the incentive effect of "the petty corruption" on company's innovation activity and also on the hampering effect of "the grand corruption" on business innovation.

So, even if in a certain context corruption enhances business innovation, in the long run, the positive effects are shaded by the burden of the proven negative effects of the corruption on the business innovation, on the business environmental stability and predictability and also on country's development level. 


\section{Methodology}

The purpose of verifying the possible influence of corruption's different dimensions on business innovation contains two principal stages. Firstly, was selected a sample of 110 emerging countries from four continents (World Bank, 2018b), such as Asia, Africa, Europe and Latin America (see Appendix Table 1) using a dataset available online on one of the World Bank databases (World Bank, 2018a), for a period of 13 years, between 2002 and 2014. The sample size was determined in accordance with the main purpose of the paper, in our attempt to highlight the possible influence of corruption on the corporate innovation activities in a representative number of developing economies. Moreover, the size of the considered sample was determined by considering the data analyse methodology which requires a consistent number of observations in order to create certain accurate informational indices. For each considered concept - corruption and business innovation - was created a composite informational index by selecting several representative variables in each of these two cases. Thus, from the desire to highlight the long-run trend of the variables were determined the means of the values over the time span. In this manner, one of the main contribution of this work is represented by the analyse of a consistent number of emergent economies from different regions of the world, focusing mainly on the way that systemic corruption affects the innovation activities of the corporate sector in a considerable period of time.

The most of the countries included in the sample have maintained their evolution over time and most of them are included in the present in the same income and development category which gives topicality to the present empirical study. Moreover, we appreciate that the considered 13-years period creates the premises of insignificant changes of the average values of the variables in the period which follows the analysed time span, the average values being not consistently influenced in case of possible oscillations.

Appealing at the method of principal components analysis, the first proposed composite index represents corruption, considering several variables offered by World Bank Database (World Bank, 2018a), such as:

1. "bribery incidence (percent of firms experiencing at least one bribe payment request)" - corruption variable A,

2. "bribery depth (percent of public transactions where a gift or informal payment was requested)" - corruption variable $\mathrm{B}$,

3. "percent of firms expected to give gifts in meetings with tax officials" - corruption variable $C$,

4. "percent of firms expected to give gifts to secure government contract" - corruption variable $\mathrm{D}$,

5. "percent of firms expected to give gifts to get an import license" - corruption variable E,

6. "percent of firms expected to give gifts to get an electrical connection" - corruption variable $\mathrm{F}$,

7. "percent of firms expected to give gifts to public officials "to get things done"” - corruption variable $\mathrm{G}$.

The proposed variables capture seven different dimensions of corruption targeting three characteristic features of it: the bribery's prevalence (corruption variable A), the bribery's 
spread (corruption variable B) and the companies' propensity to offer gifts for overcoming the bureaucratic pressures (corruption variables $C, D, E, F$ and G).

In the same manner, were selected several variables that illustrate different dimensions of business innovation, like:

1. "percent of firms with an internationally-recognized quality certification" - business innovation variable $\mathrm{A}$,

2. "percent of firms having their own Web site" - business innovation variable B,

3. "percent of firms using e-mail to interact with clients/suppliers" - business innovation variable $\mathrm{C}$,

4. "percent of firms with an annual financial statement reviewed by external auditors" business innovation variable $\mathrm{D}$.

All these variables describe four different dimensions of innovation less approached so far. These variables are targeting the company's openness for innovation regarding the way it is connected with its business partners (clients, suppliers), also the interface between the company and its stakeholders, as well as for innovating the company's image and strengthening it.

Generally, in their studies, authors have considered one or two different dimensions of innovation (Dincer, 2019; Tomaszewski, 2018). In our research, based on the World Bank Database (World Bank, 2018a), we have considered four new relevant dimensions of innovation, less addressed so far in the literature. The nature and characteristics of these four dimensions of innovation assign a novelty character and originality to this research study. In order to preserve the originality of research, we considered it necessary to limit the number of innovation dimensions to only these four variables. Increasing the number of variables would have determined the consideration of some other variables, already extensively addressed in the literature. The relevance of using these four dimensions of innovation is offered by the importance of having internationally recognized quality certificates in order to develop more effective activities and to obtain successful outcomes. This type of concerns, along with the organization's ability to use the internet in business transactions, are able to stimulate the corporate productivity and company's success on the market.

Increasing customer demands towards products and services quality is leading more and more companies to pay more attention to quality continuous improvement and sustainability. Thus, companies are becoming increasingly aware of this issue focusing on innovations aimed at proving their products' compliance with international quality standards and meeting customer's expectations.

Having their own Web site, the companies stay competitive and gain higher visibility on the market. Such a choice proves a strong customer orientation and will allow these companies to strengthen their brand, will assure a much better presentation of the company, of the products and services offered to customers, and a rapid increase in its sales volume. Acting in the online environment the company shows its orientation towards innovation in products and services promotion, entering new markets and the use of new distribution channels.

Using e-mail as a way of networking with customers and suppliers highlights the company's concern for innovations aimed at an effective communication with its business partners. Choosing this channel for communication has the main advantages of increased speed, 
overcoming geographical barriers, cost reduction, improved customer services and targeted marketing.

The objective pursued by companies that have an annual financial statement reviewed by external auditors is that of providing a high level of credibility to the financial status and the performance of the company. These companies are proving to be oriented towards innovations aimed at enhancing the transparency, strengthening the business image and also increasing the company's credibility in business relationships.

Aiming to retain the most representative variables from each field of study, the methodology of principal component analysis (PCA) has been used to develop both indicators. This framework supposes the reduction of a data set dimension characterized by a huge number of variables which are interrelated. The result of this methodology is a new data set of uncorrelated variables ordered so that the first ones keep the most of the variation that describes all of the original variables (Jolliffe, 2002, p. 1). Thus, the co-variation of considered variables is described by the existence of some latent variables that has a causal impact on the studied variables. The main purpose of this framework is represented by the reduction of data set dimension through creation of some new, artificial and relevant composite variables named principal components. In this case, each new variable, principal component, describes a linear combination of the selected variables, being in the same time a reflection of the prevalent patterns in the data set. The main reason of using this methodology consists in assumption that selected variables are strongly correlated and in endeavour to reduce the dimension of interrelated variables, preserving the global variation of dataset (for more details see Jolliffe, 2002; Dima, Ionescu, \& Tudoreanu, 2013). Thereby, the principal component analysis represents a statistical technique which allows the conversion of the data in case of presumably correlated variables into a database of values of linearly uncorrelated variables. In this manner, the methodology can represent a significant tool in order to reduce multidimensional data to a smaller number of dimensions while maintaining the most part of the information.

The second stage of the paper consist in testing the possible impact of corruption index on business innovation one, using the framework of generalized linear model (GLM). This framework represents an extension of simple linear regression, because it allows analyse of non-normal distributed data, being a supple propose for ordinary least squares regression (for more details see Nelder \& Wedderburn, 1972; McCullagh \& Nelder, 1989). Considering the dataset's main features, the GLM implementation was made using an "Identity link function", a Gaussian distribution, which is widely used in case of variables with unknown distribution, and Newton-Raphson process to check the robustness of results.

Moreover, in order to verify the robustness of our empirical results and hypothesis, the GLM framework includes two variables of control, such as "Scientific and technical journal articles" and "Exports of goods and services (\% of GDP)". These control variables were determined in the same manner, as an average for the considered 13-years period, between 2002 and 2014, and we anticipated positive coefficients for both of them. In order to increase the robustness of our research, the relevance of considered control variables is offered by the fact that, on the one hand, the scientific articles published by the journals contributes directly to the progress of science and human civilization by reporting the new results of research and, 
on the other hand, exports of goods and services implies a certain level of economy's openness, being able to stimulate the company's innovation activities in attempts of increasing its international competitiveness. In this framework, the companies have the opportunity to gain expertise in production process of goods and services, gaining knowledge and having the possibility to offer high wages, happiness and high standard of living for its workforce. Thus, the control variables role is to estimate with a high level of accuracy the influence of independent variable on the dependent one - business innovation index in our case. In this manner, the model retains the anticipated positive effects of these two control variables and focus more on the effect of the corruption on business innovation activities in case of considered sample.

In this framework, the proposed model aims to test the possible impact of corruption composite index on business innovation composite index, as it can be observed in the bellow equation:

$$
I N=\alpha \cdot \operatorname{Corr}+\beta \cdot X_{1}+\gamma \cdot X_{2}+\varepsilon, \varepsilon \in N(\sigma, 0),
$$

where: $I N=$ business innovation index; Corr = corruption index; $X_{1}=$ the first control variable ("Scientific and technical journal articles"); $X_{2}=$ the second control variable ("Exports of goods and services, \% of GDP”); $\varepsilon=$ error term.

Given that this paper analyses a causal process based on time series data, there is possible that a question of endogeneity existence arise, i.e. a correlation between the independent variable - in our case, the Corruption index - and the error term of the model. One method that we have applied in order to alleviate the endogeneity was to compute the indexes used in the regression model in the form of averages of the values recorded during the analysed period. We also intended to avoid this problem of endogeneity by introducing two control variables in the model. Moreover, the research design of the paper is constructed so that the causality between the Business innovation index and Corruption index is relevant and the chances of significant endogeneity were reduced. However, a limit of the paper may be that no specific tests have been performed to determine endogeneity, for which a certain bias of the estimated values may affect the model.

\section{Empirical results}

Table 1 illustrates the empirical results of principal component analysis methodology for variables from corruption field. In the first part of the table can be seen information regarding the number of principal components, while the next section highlights the situation of eigenvectors. Thus, empirical results reveal that first component summarizes $76 \%$ from the group's variance and together with the second component these describes $84 \%$ of the total variance of variables. This considerable cumulative percent of group's variance represented by first two principal components allows us to build a composite index related to corruption field from considered emerging countries.

Regarding the eigenvectors situation, the second section of Table 1 shows the linear combination of coefficients in case of the first retained component. In this regard, it can be noticed that in case of the first principal component exists an approximately equal linear combination of all seven proposed variables representing corruption, all of them having val- 
ues between 0.32 and 0.42 , which allows appreciating this as a significant index of corruption in analysed sample.

Table 1. PCA in the case of corruption variables

\begin{tabular}{|c|c|c|c|c|}
\hline \multicolumn{5}{|c|}{ Eigenvalues (Sum $=7$, Average = 1) } \\
\hline Comp. & Amount & Diff. & Share (\%) & Cumulative share (\%) \\
\hline 1 & 5.33 & 4.79 & 0.76 & 0.76 \\
\hline 2 & 0.55 & 0.09 & 0.08 & 0.84 \\
\hline 3 & 0.46 & 0.15 & 0.07 & 0.91 \\
\hline 4 & 0.31 & 0.12 & 0.04 & 0.95 \\
\hline 5 & 0.19 & 0.05 & 0.03 & 0.98 \\
\hline 6 & 0.14 & 0.13 & 0.02 & 0.999 \\
\hline 7 & 0.01 & - & 0.002 & 1.00 \\
\hline \multicolumn{7}{|c|}{ Eigenvectors (loadings): } \\
\hline \multicolumn{7}{|c|}{ Corruption variable A } \\
\hline
\end{tabular}

Notes: Observations: 110; Computed: Ordinary correlations; Extracted 7 of 7 potential components. Data source: own elaboration based on World Bank database (www.enterprisesurveys.org).

Using the same framework of PCA for variables related to business innovation, in Table 2 can be seen the obtained results. Thus, the first component includes $57 \%$ from the global variance, while the second component provides $21 \%$ of this variance. Therefore, in case of first two principal components there is a cumulative percent of $78 \%$ of the group variance. In addition, the second section of the table shows close values for linear combination of coefficients, which permit us to consider it a significant composite index in order to express business innovation in analysed countries.

Following the development of the proposed indicators, the second direction of the paper is to test the initial assumption - the possible influence of corruption index over business innovation one. Therefore, Table 3 shows the empirical results of applying GLM framework regarding the proposed concepts. The model supposes that business innovation index represents the dependent variable, aiming to test the impact of the corruption index over it. Moreover, as we already mentioned, in the model were included two independent variables as control variables for robustness of the results. In case of these two control variables - "Scientific and technical journal articles" and "Exports of goods and services (\% of GDP)" - we anticipate a positive and significant influence upon business innovation, considering their 
Table 2. PCA in the case of business innovation variables

\begin{tabular}{|c|c|c|c|c|}
\hline \multicolumn{5}{|c|}{ Eigenvalues (Sum = 4, Average = 1) } \\
\hline Comp. & Amount & Diff. & Share (\%) & Cumulative share (\%) \\
\hline 1 & 2.28 & 1.43 & 0.57 & 0.57 \\
\hline 2 & 0.85 & 0.18 & 0.21 & 0.78 \\
\hline 3 & 0.67 & 0.48 & 0.17 & 1.00 \\
\hline 4 & 0.20 & - & 0.05 & Principal component 1 \\
\hline \multicolumn{7}{|c|}{ Variables } & 0.46 \\
\hline \multicolumn{7}{|c|}{ Eigenvectors (loadings): } \\
\hline Business innovation variable A & 0.56 \\
\hline Business innovation variable B & 0.58 \\
\hline Business innovation variable C & 0.36 \\
\hline
\end{tabular}

Notes: Observations: 110; Computed: Ordinary correlations; Extracted 4 of 4 potential components. Data source: own elaboration based on World Bank database (www.enterprisesurveys.org).

Table 3. GLM model of corruption index influence on business innovation index (source: own computation based on World Bank database (www.enterprisesurveys.org))

\begin{tabular}{|l|c|c|}
\hline \multirow{2}{*}{\multicolumn{1}{|c|}{ Variables }} & Dependent variable: Business Innovation Index \\
\cline { 2 - 3 } & Coefficients & Robust standard errors \\
\hline Corruption Index & $-0.29^{* * *}$ & 0.05 \\
\hline $\begin{array}{l}\text { The first control variable - "Scientific } \\
\text { and technical journal articles" }\end{array}$ & $0.0001^{* * *}$ & 0.00002 \\
\hline $\begin{array}{l}\text { The second control variable - "Exports } \\
\text { of goods and services (\% of GDP)" }\end{array}$ & $0.03^{* * *}$ & 0.01 \\
\hline Observations & & 110 \\
\hline Pearson SSR & \multicolumn{2}{|c|}{137.86} \\
\hline Pearson statistic & \multicolumn{2}{|c|}{1.30} \\
\hline Log likelihood & -168.5 \\
\hline Modified Akaike Information Criterion & 3.14 \\
\hline Bayesian Information Criterion & -360.39 \\
\hline
\end{tabular}

Observations: Levels of statistical significance of $10 \%, 5 \%$, and $1 \%$, are represented with ${ }^{*}$, ${ }^{* *}$ and ${ }^{* * *}$. GLM: a) Gaussian family; b) Identity link function; c) Newton-Raphson algorithm of optimization.

supposed importance in ensuring of an adequate environment, capable to stimulate innovation of corporate sector.

The empirical results revealed in Table 3 show that the corruption index has a strong negative influence on business innovation index, with a statistical significance level of $1 \%$. More than that, both control variables influence positively innovation index, having as well a statistical significance level of $1 \%$. 


\section{Conclusions}

The opportunity of this study is based on the existence in the literature of some completely opposed approaches regarding the influence of corruption on business innovation. The views on the effect of corruption on innovation are so different and even contradictory in some situations, due to contextual factors considered, such as the efficiency of governmental structures and institutions, the extent of corruption, the type of innovation, the approach level: business or national, the level of countries development. Thus, when the corruption-innovation relationship was approached from the perspective of the company's inclination towards innovation, corruption has been proven to have a negative impact on innovation. But at the same time, considering the relationship between the two variables from another perspective, corruption was approached as a beneficial tool to overcome the red tape hindrances in order to facilitate product innovation in companies.

Thus, in literature there are several arguments both to support a negative influence of corruption on business innovation, known as the "sanding the wheels" approach, and also to support the "greasing the wheels" approach, suggesting that under certain circumstances and in a certain time horizon, corruption may have a boosting effect on business innovation.

In this framework, the present study analysed the possible impact of corruption on companies' innovation activity, using a sample of 110 emerging states from different areas such as Asia, Africa, Europe and Latin America. The subject of this research study is very topical, fitting in the trend of intensifying researches highlighting the relationship between the different dimensions of corruption and various measures of innovation in emerging states. The essential addition of this paper at the existing literature relies in considering various variables which describe corruption at governmental structures and institutions' level and in testing their influence on a proposed composite index which describes several business innovation dimensions. The findings of this study are valuable because, for a more comprehensive approach of the corruption's influence on business innovation, considers seven different dimensions of corruption targeting three characteristic features of it, as bribery's prevalence, the bribery's spread and the companies' propensity to offer gifts for overcoming the bureaucratic pressures. Also, this study is considering four different new dimensions of business innovation which approach innovation from a new perspective, less studied until now. These new dimensions of business innovation are targeting the company's propensity for innovating and strengthening its image and the way of connecting with business partners in a changing business environment. By considering four new dimensions of innovation, this study reveals new perspectives to address the relationship between the corruption at governmental structures and institutions' level and the business innovation in the specific context of emerging countries.

Thus, following the empirical results presented above, we can appreciate that our research hypothesis was confirmed and corruption affects both negatively and significantly the innovation processes of the companies in emerging countries. This phenomenon is able to create a negative and unstable environment that discourages the corporate innovation process. The negative influence of corruption on the companies' innovation propensity is emphasized especially in emerging countries. So the findings of this research study are strong additional arguments that complement the literature supporting the "sanding the wheels" approach, contributing to its reinforcement. 
In this respect, it is expected that increasing the anti-corruption efforts and reducing the level of corruption will generate a boosting effect on the corporate sector's innovation process.

The limitation of this research consists in that the available data for emerging countries in the analysed period of time do not allow a wider study to consider even more dimensions of corruption and, respectively, more dimensions of business innovation. Thus, the future research possibilities can extend the present study by including a larger area of emerging countries in the sample of considered countries. Also, the study can be continued by analysing the possible different effects of corruption on business innovation according with the different countries' development levels. As well, depending by the availability of updated data, further research may extend the complexity of analyse by taking into consideration of some new possible measures or dimensions which are able to describe the concepts of corruption or business innovation.

\section{Author contributions}

Gabriela Lucia Sipos and Alin Ionescu conceived the study and were responsible for the design and development of the data analysis. Gabriela Lucia Sipos and Marilen Gabriel Pirtea were responsible for documenting the relevance and timeliness of the proposed research topic and also for the theoretical background. Alin Ionescu was responsible for data collection and analysis. Marilen Gabriel Pirtea, Alin Ionescu and Gabriela Lucia Sipos were responsible for data interpretation, conclusions and for writing the first draft of the article. All the three authors agreed the final version of the article.

\section{Disclosure statement}

The authors of this article don't have any competing financial, professional, or personal interests from other parties.

\section{References}

Abdi, K., Mardani, A., Senin, A. A., Tupenaite, L., Naimaviciene, J., Kanapeckiene, L., \& Kutut, V. (2018). The effect of knowledge management, organizational culture and organizational learning on innovation in automotive industry. Journal of Business Economics and Management, 19(1), 1-19. https://doi.org/10.3846/jbem.2018.1477

Alam, A., Uddin, M., \& Yazdifar, H. (2019). Institutional determinants of R\&D investment: Evidence from emerging markets. Technological Forecasting and Social Change, 138, 34-44. https://doi.org/10.1016/j.techfore.2018.08.007

Anokhin, S., \& Schulze, W. (2009). Entrepreneurship, innovation, and corruption. Journal of Business Venturing, 24, 465-476. https://doi.org/10.1016/j.jbusvent.2008.06.001

Ayyagari, M., Demirgüç-Kunt, A., \& Maksimovic, V. (2014). Bribe payments and innovation in developing countries: are innovating firms disproportionately affected? Journal of Financial and Quantitative Analysis, 49(1), 51-75. https://doi.org/10.1017/S002210901400026X 
Barasa, L. (2018). Corruption, transaction costs and innovation in Africa. African Journal of Science, Technology, Innovation \& Development, 10(7), 811-821.

https://doi.org/10.1080/20421338.2018.1519061

Begovic, B. (2005). Corruption: concepts, types, causes and consequences. Centre for International Private Enterprises, Washington DC. Retrieved from https://www.researchgate.net/publication/265364211_ Corruption_Concepts_types_causes_and_consequences

Blackburn, K., \& Forgues-Puccio, G. F. (2009). Why is corruption less harmful in some countries than in others? Journal of Economic Behavior \& Organization, 72(3), 797-810. https://doi.org/10.1016/j.jebo.2009.08.009

Botrić, V., \& Božić, L. (2015). Innovators' vs. Non-innovators' perceptions of corruption in European post-transition economies. DIEM, 2(1), 245-258. Retrieved from https://hrcak.srce.hr/file/238181

Chandan, S., \& Arup, M. (2015). Corruption, governance and firm performance: evidence from Indian enterprise. Journal of Policy Modelling, 37, 835-851. https://doi.org/10.1016/j.jpolmod.2015.05.001

Dang, L. (2016). Does China’s anti-corruption campaign promote corporate innovation? China Economist, 11(2), 95-108.

de Waldemar, F. S. (2012). New products and corruption: evidence from Indian firms. The Developing Economies, 50(3), 268-284. https://doi.org/10.1111/j.1746-1049.2012.00171.x

Dickel, P., \& Graeff, P. (2018). Entrepreneurs' propensity for corruption: A vignette-based factorial survey. Journal of Business Research, 89, 77-86. https://doi.org/10.1016/j.jbusres.2018.03.036

Dima, B., Ionescu, A., \& Tudoreanu, P. (2013). Corporate governance and financial structures of companies in developing countries. Annales Universitatis Apulensis Series Oeconomica, 15(1), 162-172. Retrieved from http://www.oeconomica.uab.ro/upload/lucrari/1520131/14.pdf

Dincer, O. (2019). Does corruption slow down innovation? Evidence from a cointegrated panel of U.S. states. European Journal of Political Economy, 56, 1-10. https://doi.org/10.1016/j.ejpoleco.2018.06.001

DiRienzo, C., \& Das, J. (2015). Innovation and role of corruption and diversity: A cross-country study. International Journal of Cross Cultural Management, 15(1), 51-72. https://doi.org/10.1177/1470595814554790

Ellis, J. A., Smith, J. D., \& White, R. M. (2016). Corruption and corporate innovation (pp. 1-51). Retrieved from https://ssrn.com/abstract $=2862128$

Ernst \& Young. (2018). 15th Global Fraud Survey. Emerging Markets Perspective. Fraud, bribery and corruption in emerging markets. Retrieved from https://fraudsurveys.ey.com/global-fraud-survey2018-emerging-markets-perspective/fraud-bribery-and-corruption-in-emerging-markets/

Gan, W., \& Xu, X. (2018). Does anti-corruption campaign promote corporate R\&D investment? Evidence from China. Finance Research Letters (In Press). https://doi.org/10.1016/j.frl.2018.10.012

Gang, X., \& Go, Y. (2017). How does anti-corruption affect corporate innovation? Evidence from recent anti-corruption efforts in China. Journal of Comparative Economics, 45(3), 498-519. https://doi.org/10.1016/j.jce.2016.10.001

Goedhuys, M., Mohnen, P., \& Taha, T. (2016). Corruption, innovation and firm growth: firm-level evidence from Egypt and Tunisia. Eurasian Business Review, 6(3), 299-322. https://doi.org/10.1007/s40821-016-0062-4

Goel, R. K., \& Nelson, M. A. (2018). Determinants of process innovation introductions: Evidence from 115 developing countries. Managerial and decision economics, 39(5), 515-525. https://doi.org/10.1002/mde.2922

Habiyaremye, A., \& Raymond, W. (2018). How do foreign firms' corruption practices affect innovation performance in host countries? Industry-level evidence from transition economies. Innovation: Organization \& Management, 20(1), 18-41. https://doi.org/10.1080/144793338.2017.1367626

Janoskova, K., \& Kral, P. (2015). Optimal timing of innovation as a precondition of successful innovation on the global market. $15^{\text {th }}$ International Scientific Conference on Globalization and its Socio- 
Economic Consequences, University of Zilina, The Faculty of Operation and Economics of Transport and Communication, Department of Economics, Zilina. Retrieved from https://www.researchgate. net/publication/321255282_OPTIMAL_TIMING_OF_INNOVATION_AS_A_PRECONDITION_ OF_SUCCESSFUL_INNOVATION_ON_THE_GLOBAL_MARKET

Jolliffe, I. T. (2002). Principal component analysis (2nd ed.). New York: Springer.

Karaman Kabadurmuş, F. N. (2017). Corruption and innovation: the case of EECA countries. Journal of Entrepreneurship and Innovation Management, 6(2), 51-71. Retrieved from http://www.betadergi. com/jeim/volume-6-issue-2-year-2017.html

Kayalvizhi, P. N., \& Thenmozhi, M. (2018). Does quality of innovation, culture and governance drive FDI?: Evidence from emerging markets. Emerging Markets Review, 34, 175-191. https://doi.org/10.1016/j.ememar.2017.11.007

Krammer, S. M. S. (2013). Greasing the wheels of change: the impact of corruption on firms' innovation in transition economies. 35th DRUID Celebration Conference 2013, Barcelona, Spain. Retrieved from https://conference.druid.dk/acc_papers/lgyvnfdybhoqndiba285rnk1frxl.pdf

Lau, C. K., Yang, F. S., Zhang Z., \& Leung, V. (2015). Determinants of innovative activities: Evidence from Europe and central Asia region. The Singapore Economic Review, 60(1). https://doi.org/10.1142/S0217590815500046

Lesakova, L., Gundova, P., Kral, P., \& Ondrusova, A. (2017). Innovation leaders, modest innovators and non-innovative SMEs in Slovakia: key factors and barriers of innovation activity. Organizacija, 50(4), 325-338. https://doi.org/10.1515/orga-2017-0024

Mahagaonkar, P. (2010). Corruption and innovation. In: Money and Ideas. International Studies in Entrepreneurship, 25, 81-97. https://doi.org/10.1007/978-1-4419-1228-2_5

Marquette, H., \& Peiffer, C. (2015). Collective action and systemic corruption, In ECPR Joint Sessions of Workshops. University of Warsaw (Vol. 29). Retrieved from https://ecpr.eu/Filestore/PaperProposal/ b5944a31-85b6-4547-82b3-0d4a74910b07.pdf

McCullagh, P., \& Nelder, J. A. (1989). Generalized linear models (2nd ed.). London: Chapman and Hall.

Meon, P. G., \& Weill, L. (2010). Is corruption an efficient grease?. World Development, 38(3), 244-259. https://doi.org/10.1016/j.worlddev.2009.06.004

Mungiu-Pippidi, A. (2015). Good governance powers innovation. Nature, 518, 295-297. Retrieved from https://www.nature.com/polopoly_fs/1.16927!/menu/main/topColumns/topLeftColumn/ pdf/518295a.pdf

Mrad, F., \& Bouaziz, N. (2018). The effects of the quality of institutions on innovation: Macroeconomic country analysis. Innovations, 57(3), 137-164. https://doi.org/10.3917/inno.pr1.0038.

Nelder, J., \& Wedderburn, R. (1972). Generalized linear models. Journal of The Royal Statistical Society, 135(3), 370-384. Retrieved from https://pdfs.semanticscholar.org/105f/0072f191a4ceb7c381fc4fd9 3f460aabf6b1.pdf

Ngoc, A. N., Quang, H. D., Ngoc, M. N., \& Binh, T. N. (2016). The impact of petty corruption on firm innovation in Vietnam. Crime Law and Social Change, 65(4), 377-394. https://doi.org/10.1007/s10611-016-9610-1

Paunov, C. (2016). Corruption's asymmetric impacts on firm innovation. Journal of Development Economics, 118, 216-231. https://doi.org/10.1016/j.jdeveco.2015.07.006

Radu, L. (2017). Corruption in the European Union and the responsibility of European institutions. Transylvanian Review of Administrative Sciences, 50 E, 164-176. https://doi.org/10.24193/tras.2017.0010

Sena, V., Duygun, M., Lubrano, G., Marra, M., \& Shaban M. (2018). Board independence, corruption and innovation. Some evidence on UK subsidiaries. Journal of Corporate Finance, 50, 22-43. https://doi.org/10.1016/j.jcorpfin.2017.12.028 
Stephenson, M. (2015). Corruption is both a "Principal-Agent Problem" and a "Collective Action Problem”. The Global Anticorruption blog, Law, Social Science and Policy. Retrieved from https://globalanticorruptionblog.com/2015/04/09/corruption-is-both-a-principal-agent-problem-and-a-collectiveaction-problem/

Teodorescu, D., Andrei, T., Roșca, I. G., Profiroiu, M., \& Turtureanu, M. (2007). Local governance and corruption of a country in the process of joining the European Union. Romanian Journal of Economic Forecasting, 8(4), 49-60. Retrieved from http://www.ipe.ro/rjef/rjef4_07/rjef4_07_3.pdf

Tian, X., Ruan, W., \& Xiang, E. (2017). Open for innovation or bribery to secure bank finance in an emerging economy: A model and some evidence. Journal of Economic Behaviour and Organization, 142, 226-240. https://doi.org/10.1016/j.jebo.2017.08.002

Tomaszewski, M. (2018). Corruption - a dark side of entrepreneurship. Corruption and innovations. Prague Economic Papers, 27(3), 251-269. https://doi.org/10.18267/j.pep.647

Uberti, L. J. (2018). Corruption in transition economies: Socialist, Ottoman or structural? Economic Systems, 42(4), 533-555. https://doi.org/10.1016/j.ecosys.2018.05.001

Veracierto, M. (2008). Corruption and innovation. Economic Perspectives, 32(1), 29-39. Retrieved from https://ssrn.com/abstract $=1096569$

Wen, J., Zheng, M., Feng, G. F., Chen, S. W., \& Chang, C. P. (2018). Corruption and innovation: linear and nonlinear investigations of OECD countries. The Singapore Economic Review, 1-27. https://doi.org/10.1142/S0217590818500273

World Bank. (1997). Helping countries to combat corruption. The role of World Bank. Washington DC: World Bank. Retrieved from http://www1.worldbank.org/publicsector/anticorrupt/corruptn/corrptn.pdf

World Bank. (2018a). Enterprise surveys. Retrieved from www.enterprisesurveys.org

World Bank. (2018b). World Bank country and lending groups - country classification. Retrieved from https://datahelpdesk.worldbank.org/knowledgebase/articles/906519-world-bank-countryand-lending-groups

Xie, X., Qi, G., \& Zhu, K. X. (2018). Corruption and new product innovation: examining firms' ethical dilemmas in transition economies. Journal of Business Ethics, 1-19. https://doi.org/10.1007/s10551-018-3804-7

Xu, G., Zhang, D. Y., \& Yano, G. (2017). Can corruption really function as "protection money" and "grease money"? Evidence from Chinese firms. Economic Systems, 41(4), 622-638. https://doi.org/10.1016/j.ecosys.2017.03.001

Yu, F., Guo, Y., Lettic, F., \& Barnes, S. J. (2019). Regional anti-corruption effort, political connections and firm innovation effort: evidence from China. Bulletin of Economic Research, 71(1), 18-32. https://doi.org/10.1111/boer.12146 


\section{APPENDIX}

Table 1. The list of the selected 110 emerging countries from 4 continents considered in the research (source: World Bank, https://datahelpdesk.worldbank.org/knowledgebase/articles/906519-world-bankcountry-and-lending-groups)

\begin{tabular}{|c|c|c|c|}
\hline $\begin{array}{l}\text { High income } \\
\text { countries }\end{array}$ & $\begin{array}{l}\text { Low income } \\
\text { countries }\end{array}$ & $\begin{array}{l}\text { Lower middle } \\
\text { income countries }\end{array}$ & Upper middle income countries \\
\hline Bahamas & Afghanistan & Angola & Albania \\
\hline Barbados & Benin & Bangladesh & Armenia \\
\hline Chile & Burkina Faso & Bhutan & Azerbaijan \\
\hline Croatia & Burundi & Bolivia & Belarus \\
\hline Czech Republic & $\begin{array}{l}\text { Central African } \\
\text { Republic }\end{array}$ & Cabo Verde & Bosnia and Herzegovina \\
\hline Estonia & Chad & Cameroon & Botswana \\
\hline Hungary & Congo, Dem. Rep. & Côte d'Ivoire & Brazil \\
\hline Latvia & Ethiopia & Djibouti & Bulgaria \\
\hline Lithuania & Madagascar & Egypt, Arab Rep. & China \\
\hline Panama & Malawi & El Salvador & Colombia \\
\hline Poland & Mali & Georgia & Costa Rica \\
\hline Slovak Republic & Mozambique & Ghana & Dominica \\
\hline Slovenia & Nepal & Honduras & Dominican Republic \\
\hline Trinidad and Tobago & Niger & India & Ecuador \\
\hline \multirow[t]{23}{*}{ Uruguay } & Rwanda & Indonesia & Fiji \\
\hline & Senegal & Kenya & Grenada \\
\hline & Tajikistan & Kosovo & Guatemala \\
\hline & Tanzania & Kyrgyz Republic & Guyana \\
\hline & Togo & Lao PDR & Jamaica \\
\hline & Uganda & Lesotho & Jordan \\
\hline & Yemen & Mauritania & Kazakhstan \\
\hline & & Moldova & Lebanon \\
\hline & & Mongolia & Macedonia, FYR \\
\hline & & Morocco & Mauritius \\
\hline & & Myanmar & Mexico \\
\hline & & Nicaragua & Montenegro \\
\hline & & Nigeria & Namibia \\
\hline & & Pakistan & Paraguay \\
\hline & & Philippines & Peru \\
\hline & & Sri Lanka & Romania \\
\hline & & Sudan & Russian Federation \\
\hline & & Swaziland & Serbia \\
\hline & & Tunisia & South Africa \\
\hline & & Ukraine & St. Vincent and the Grenadines \\
\hline & & Vanuatu & Tonga \\
\hline & & Vietnam & Turkey \\
\hline & & Zambia & Venezuela, R.B. \\
\hline
\end{tabular}

